\title{
Diamonds from the Deep: Pipe DO-27, Slave Craton, Canada
}

\author{
Davies, R. ${ }^{1}$, Griffin, W.L. ${ }^{1,2}$, Pearson, N.J. ${ }^{1}$, Andrew, A. ${ }^{3}$, Doyle, B.J. ${ }^{4}$ and O'Reilly, S.Y. ${ }^{1}$ \\ 1. GEMOC National Key Centre, Macquarie University, NSW 2109, Australia \\ 2. CSIRO Exploration and Mining, P.O. Box 136, N.Ryde, NSW 2113, Australia \\ 3. CSIRO Div. of Petroleum Exploration, P.O. Box 136, N.Ryde, NSW 2113, Australia \\ 4. Kennecott Canada Inc., 200 Granville St., Vancouver, B.C., Canada V6C 1S4
}

This is the first report of an ongoing investigation of diamonds (mineral inclusions, diamonds' physical and chemical characteristics) from kimberlite pipe DO-27, near Lac de Gras in the Slave Craton, Canada. This study is a component of our Lithosphere Mapping project on the Slave Craton, which integrates petrological and geophysical data to understand the composition, structure and origin of the lithospheric mantle; this information is critical to diamond exploration models for the Slave Craton, which has a unique lithospheric structure (Griffin et al., this volume).

Physical Characteristics

Diamonds examined weigh between 0.01 and 0.42 carats; $75 \%$ were $<0.10$ carat. $75 \%$ of the stones are coloured, from shades of brown (55\%) to yellow/brown (5\%), yellow $(9 \%)$ and grey (6\%). Morphology ranges from planar octahedra and composite octahedra with minor resorption (30\% of stones) to heavily resorbed dodecahedra. All resorption categories (Robinson et al., 1989) are represented, and more than half of the diamonds have lost $25 \%$ to $65 \%$ of their original mass. Resorbed forms consist of equal proportions of dodecahedra, flattened dodecahedra, aggregates and fragments with resorbed external faces. $12 \%$ of stones are cubes and cubo-octahedra, many of which are fibrous and/or have hopper faces. Octahedral diamonds have smooth finely stepped planar surfaces and ribbed edges. Negative etch trigons and hexagons are common on primary faces. Dodecahedral forms preserve dissolution laminae and large drop-shaped hillocks. Ruts are common and resorbed surfaces are often frosted. Slip plane dislocations resulting from plastic deformation are evident on about half the stones, as glide planes and shagreen texture on resorbed dodecahedral faces.

\section{Diamond Inclusions}

Mineral inclusions were extracted by breaking diamonds in an enclosed cell, then placed in epoxy on glass slides and polished for electron microprobe analysis. Small inclusions exposed on cleavage surfaces were analysed in situ. Representative analyses are given in Table 1.

Eclogitic paragenesis: $\approx 50 \%$ of the inclusions are eclogitic. Eclogitic garnets have $9-16 \%$ $\mathrm{CaO}$ and variable $\mathrm{Na}_{2} \mathrm{O}$ contents; no majorite component is present. Their composition suggests they are derived from kyanite-bearing eclogites, similar to observed xenoliths (Pearson et al., this vol.). One "omphacite" has a high level of opx solid solution, implying a high-T origin; another contains $\mathrm{Jd}=25 \%$. Diopside inclusions also occur but may be epigenetic (Table 1$)$. Low-Ni $(<2.9 \% \mathrm{Ni})$ iron sulfides of the eclogite paragenesis were recovered from 5 diamonds .

Peridotitic paragenesis: This paragenesis includes olivine, $\mathrm{Cr}$-pyrope and pentlandite. Pyrope inclusion $27 \mathrm{G}$ has very high $\mathrm{Cr}_{2} \mathrm{O}_{3}$, but is only mildly subcalcic. It is extremely depleted in $\mathrm{Y}$ and $\mathrm{Zr}$, but contains significant $\mathrm{Sr}$, as is typical of diamond-inclusion $\mathrm{Cr}$-pyrope garnets. Two lherzolitic garnets intergrown with diamonds give $\mathrm{T}_{\mathrm{Ni}}=1130^{\circ} \mathrm{C}$ and $920^{\circ} \mathrm{C}$. All of the olivines have high mg\# (92.8-94.0), suggesting a harzburgitic paragenesis. One pentlandite inclusion has been recovered.

Super-deep paragenesis : At least $25 \%$ of the inclusion-bearing stones contain inclusions of ferropericlase $((\mathrm{Fe}, \mathrm{Mg}) \mathrm{O})$ or $\mathrm{Mg}$-perovskite. The ferropericlase inclusions have $\mathrm{mg \# ,} \mathrm{Cr}$ and $\mathrm{Ni}$ contents similar to inclusions reported from Orroroo, Koffiefontein and Sloan (Scott-Smith et al., 1984; Otter and Gurney, 1989). In diamond 14A the ferropericlase is accompanied by an inclusion with $\mathrm{MgSiO} 3$ stoichiometry, interpreted as the corresponding Mg-perovskite phase, and by a tiny inclusion of essentially pure $\mathrm{Ni}$.

Phlogopite and other possible epigenetic phases. Diamond 26D contained a granular mass of phlogopite with irregular intergrowths of heterogeneous almandine garnet and diopside. This assemblage is believed to be due to infiltration of fluids along a crack between two parts of the stone. Phlogopite, calcite, sphene and phlogopite + diopside + calcite intergrowths have been found in other stones. 
FIGURE 1. Carbon-Isotope compositions of DO27 diamonds

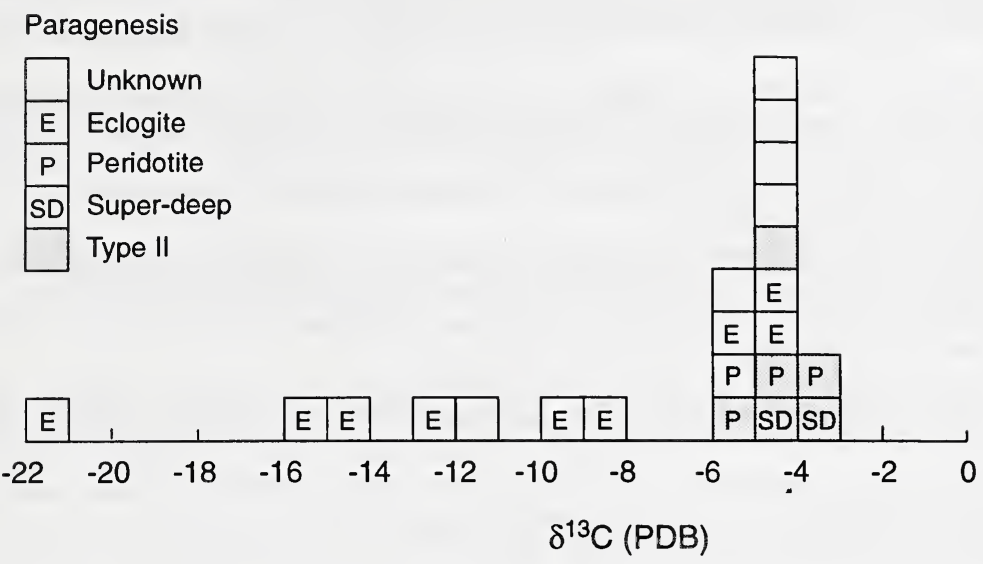

Carbon Isotopes

Carbon isotopes were measured by mass spectrometry on $0.1 \mathrm{mg}$ fragments. $2 / 3$ of the $\partial^{13} \mathrm{C}$ values lie between $3.5 \%$ and $-5.5 \%$; the remainder scatter to very low values (Fig. 1). Peridotitic diamonds cluster in the main peak, while eclogitic diamonds range from $-4.1 \%$ to $21.1 \%$. Eclogitic garnets have the lightest carbon values $<-15 \%$, while eclogitic sulfides and omphacite range between -4.1 and $-14.4 \%$. The

isotopically light carbon of the eclogitic diamonds is taken as evidence of crustal derivation of the carbon.

\section{FTIR Characteristics}

Nitrogen contents and aggregation states were calculated by deconvolution of FTIR absorbance spectra of whole stones, using the guidelines of Mendelssohn and Milledge (1995). The eclogitic and peridotitic paragenesis diamonds have similar $\mathrm{N}$ contents and $\mathrm{N}$-aggregation characteristics. $2 / 3$ of the diamonds are of the IaA-IaB type; nitrogen contents are $200-900 \mathrm{ppm}$ (mean 500). Nitrogen aggregation states show a bimodal distribution: one mode, with $<20 \% \mathrm{IaB}$, is more common to the eclogitic diamonds which also have higher average $\mathrm{N}$ contents; the other mode scatters between $40-80 \% \mathrm{IaB}$, and \% IaB does not correlate with higher $\mathrm{N}$ contents. The diamonds with high aggregation states all show plastic deformation, which is inferred to enhance nitrogen aggregation (Evans et al., 1995) 35\% of the diamonds contain no detectable nitrogen (Type II). All diamonds with the superdeep inclusion phases are Type II, as in the Sao Luiz diamond suite (Wilding et al., 1991). Other Type II diamonds are peridotitic (olivine and Cr-pyrope inclusions), and ca $10 \%$ of the eclogitic diamonds are Type II. $\mathrm{CO}_{2}$ has only been found in eclogitic diamonds (cf Chinn et al., 1995).

\section{Conclusions}

The correlation of nitrogen contents and carbon isotope compositions with inclusion paragenesis suggests that the non-inclusion bearing diamonds in this study are derived largely from the eclogitic paragenesis and the "superdeep" ferropericlase-bearing paragenesis. Based on this limited sample, we estimate that $\geq 50 \%$ of the diamonds are eclogitic, and $\approx 25 \%$ of the superdeep paragenesis.

The "superdeep" mineral assemblage represented by the ferropericlase and Mg-perovskite inclusions is stable only at lower-mantle depths $(>650 \mathrm{~km})$, and its occurrence in diamond-inclusion suites has been interpreted as evidence for the ascent of plumes from the lower mantle or from the core-mantle boundary (Scott-Smith et al., 1984; Kesson and Fitz Gerald, 1991). Its presence at Lac de Gras may have major genetic implications for the other diamonds as well. The association of abundant "superdeep" inclusions with a high proportion of eclogitic diamonds, many of which have very low $\partial^{13} \mathrm{C}$, suggests to us that a significant proportion of the diamonds from DO27 originated in the deep mantle, in a volume that contained a high proportion of subducted crustal material. The ascent of a megalithic diapir (Ringwood, 1982, Haggerty, 1994) containing this subducted material may have played an important role in the construction of the lithosphere beneath the Slave Craton. In particular, it may have produced the unique two-layered lithospheric mantle found beneath the Lac de Gras region (Griffin et al., this volume).

\section{References}

Chinn, I.L., Gurney, J.J., Milledge, H.J., Taylor, W.R. and McCallum, M.E., 1995, CO2-bearing diamonds from the George Creek K1 kimberlite dyke of the Colorado-Wyoming State Line district, Abst. 6th Int. Kimb. Conf., 113115. 
Evans, T., Kiflaw, I., Luyten, W., van Tendeloo, G. and Woods, G.S., 1995, Conversion of platelets into dislocation loops and voidite formation in Type IaB diamonds, Proc. R. Soc. Lond.A, 449, 295-313.

Haggerty, S.E., 1994, Superkimberlites: A geodynamic diamond window to the Earth's core, Earth. Planet. Sci. Lett., $122,57-69$.

Kesson, S.E. and Fitz Gerald, J.D., 1991, Partitioning of $\mathrm{MgO}$, FeO, NiO, $\mathrm{MnO}$ and $\mathrm{Cr} 2 \mathrm{O} 3$ between magnesian silicate perovskite and magnesiowustite: implications for the origin of inclusions in diamond and the compositin of the lower mantle, Earth Planet. Sci. Lett., 111,229-240.

Mendelssohn, M.J. and Milledge, H.J., 1995, Geologically significant information from routine analysis of the midInfrared spectra of diamonds, Int. Geol. Rev., 37, 95-110.

Otter, M.L. and Gurney, J.J., 1989. Mineral inclusions in diamond from the Sloan diatremes, Colorado-Wyoming State Line kimberlti district, N. America, Geol. Soc. Australia Spec. Publ., 14, 2, 1042-1053.

Ringwood, A.E., 1982, Phase transformations and differentiation in subducted lithosphere: Implications for mantle dynamics, basalt petrogenesis and crustal evolution, Jour. Geol., 90, 611-643.

Robinson, D. N., Scott, J. A., van Niekerk, A. and Anderson, V. G., 1989, The sequence of events reflected in the diamonds of some southern African kimberlites: In Kimberlites and Related Rocks Geol. Soc. Australia Spec. Publ., 14, 990-1000.

Scott-Smith, B.H., Danchin, R.V., Harris, J.W. and Stracke, K.J., 1984, Kimberlites near Orroroo, South Australia, In J. Kornprobst (ed.), Kimberlites and related rocks, Elsevier, Amsterdam, pp 121-142.

Wilding, M.C., Harte, B. and Harris, J.W., 1991, Evidence for a deep origin for the Sao Luiz diamonds, Abst. 5th Int. Kimb. Conf., 456-458.

Table 1. Representative analyses of inclusions in DO-27 diamonds

\begin{tabular}{|l|llll|llll|}
\hline Paragen. & Superdeep & & & & Peridotitic & & & \\
Sample & $15 \mathrm{~B}(1)$ & $14 \mathrm{~A}(8)$ & $14 \mathrm{~A}(8)$ & $14 \mathrm{~A}(8)$ & $15 \mathrm{~B}$ & $22 \mathrm{~B}(2)-1$ & $27 \mathrm{G}$ & Diam. 1 \\
Phase & Fe-Pericl. & Fe-pericl. & $\mathrm{Mg}$-Perov. & Ni metal & Olivine & Olivine & Cr-Pyr. & Cr-Pyr. \\
$\mathrm{SiO} 2$ & 0.03 & 0.04 & 57.22 & 0.00 & 41.22 & 41.44 & 40.26 & 41.04 \\
$\mathrm{TiO} 2$ & 0.02 & 0.01 & 0.03 & 0.02 & 0.00 & 0.01 & 0.17 & 0.2 \\
$\mathrm{Al} 2 \mathrm{O} 3$ & 0.17 & 0.08 & 2.03 & 0.01 & 0.02 & 0.02 & 11.91 & 15.72 \\
$\mathrm{Cr} 2 \mathrm{O} 3$ & 0.45 & 0.67 & 0.36 & 0.00 & 0.06 & 0.05 & 14.76 & 10.31 \\
$\mathrm{FeO}$ & 29.69 & 20.97 & 4.22 & $0.79(\mathrm{Fe})$ & 7.06 & 6.90 & 7.11 & 7 \\
$\mathrm{MnO}$ & 0.31 & 0.23 & 0.07 & 0.03 & 0.09 & 0.06 & 0.15 & 0.39 \\
$\mathrm{MgO}$ & 68.44 & 78.25 & 36.11 & 0.00 & 51.66 & 51.51 & 20.01 & 18.22 \\
$\mathrm{CaO}$ & 0.02 & 0.09 & 0.13 & 0.00 & 0.04 & 0.03 & 5.00 & 6.91 \\
$\mathrm{Na2O}$ & 0.07 & 0.27 & 0.04 & 0.00 & 0.00 & 0.00 & 0.02 & 0 \\
$\mathrm{~K} 2 \mathrm{O}$ & 0.01 & 0.04 & 0.00 & 0.02 & 0.00 & 0.01 & 0.00 & 0 \\
$\mathrm{NiO}$ & 1.55 & 1.28 & 0.03 & $96.2(\mathrm{Ni})$ & 0.34 & 0.30 & 0.00 & 0 \\
$\mathrm{Total}$ & 100.76 & 101.92 & 100.25 & 97.1 & 100.51 & 100.33 & 99.39 & 99.79 \\
$\mathrm{mg} \#$ & 80.4 & 86.9 & 93.8 & & 92.9 & 93.0 & 83.4 & 82.3 \\
\hline $\mathrm{Paragen}$. & $\mathrm{Eclogitic}$ & & & & Epigenetic? & & & \\
$\mathrm{Sample}$ & $\mathrm{D} 27-28$ & $22 \mathrm{I}$ & $23 \mathrm{j}$ & $27 \mathrm{~F}$ & $26 \mathrm{~d}$ & $26 \mathrm{~d}$ & $26 \mathrm{~d}$ & $12 \mathrm{E}(\mathrm{lc})$ \\
$\mathrm{Phase}$ & $\mathrm{Garnet}$ & $\mathrm{Garnet}$ & $\mathrm{Garnet}$ & $\mathrm{Cpx}$ & Phlogopite & Garnet & $\mathrm{Cpx}$ & $\mathrm{Cpx}$ \\
$\mathrm{SiO} 2$ & 42.73 & 39.27 & 39.48 & 54.30 & 41.02 & 41.10 & 53.88 & 53.67 \\
$\mathrm{TiO} 2$ & 0.79 & 0.97 & 0.82 & 0.41 & 3.83 & 0.01 & 0.31 & 0.47 \\
$\mathrm{~A} 12 \mathrm{O} 3$ & 19.31 & 21.07 & 21.21 & 5.48 & 12.21 & 23.04 & 0.7 & 0.65 \\
$\mathrm{Cr} 2 \mathrm{O} 3$ & 0.07 & 0.06 & 0.06 & 0.07 & 0.18 & 0.02 & 0.45 & 0.05 \\
$\mathrm{FeO}$ & 14.16 & 16.80 & 16.00 & 7.93 & 5.43 & 9.12 & 3.17 & 5.17 \\
$\mathrm{MnO}$ & 0.29 & 0.40 & 0.38 & 0.10 & 0.06 & 0.20 & 0.08 & 0.09 \\
$\mathrm{MgO}$ & 9.87 & 8.58 & 8.81 & 12.55 & 21.64 & 18.29 & 17.62 & 15.58 \\
$\mathrm{CaO}$ & 13.05 & 12.46 & 13.03 & 14.56 & 0.04 & 6.87 & 22.52 & 23.04 \\
$\mathrm{Na} 2 \mathrm{O}$ & 0.11 & 0.20 & 0.20 & 3.53 & 0.24 & 0.04 & 0.52 & 0.57 \\
$\mathrm{~K} 2 \mathrm{O}$ & 0.00 & 0.00 & 0.00 & 0.16 & 10.08 & 0.02 & 0.02 & 0.02 \\
$\mathrm{NiO}$ & 0.00 & 0.00 & 0.00 & 0.05 & 0.19 & 0.00 & 0.06 & 0.00 \\
$\mathrm{Total}$ & 100.38 & 99.81 & 99.99 & 99.14 & 94.92 & 98.71 & 99.33 & 99.32 \\
$\mathrm{mg} \#$ & 55.39 & 47.7 & 49.5 & 73.8 & 87.7 & 78.10 & 90.8 & 84.31 \\
\hline
\end{tabular}

